\title{
Drug Started Identifier
}

National Cancer Institute

\section{Source}

National Cancer Institute. Drug Started Identifier. NCI Thesaurus. Code C69273.

An identifier for a drug for which administration has started. 